\title{
GLAUCOMA TREATED WITH DIAMOX*† PRELIMINARY REPORT OF 20 CASES
}

\author{
BY
}

\author{
S. M. DRANCE \\ Oxford
}

THE use of Diamox in glaucoma logically follows Friedenwald's concept that the bicarbonate ion is secreted in the production of aqueous. Diamox is a powerful inhibitor of carbonic anhydrase and has been shown to be safe for human beings. By preventing, in part, the secretion of bicarbonate it diminishes aqueous production and consequently lowers intra-ocular pressure.

The use of Diamox in glaucoma was first reported by Becker (1954) and further annotated by Grant and Trotter (1954).

The present paper is intended as a preliminary report of the first twenty cases of glaucoma treated with Diamox in the Ophthalmic Department of the Edinburgh Royal Infirmary.

\section{Material}

The patients treated comprised twelve cases of secondary glaucoma, six of congestive glaucoma, and two of chronic primary glaucoma. The particulars of age, sex, and previous history are given in Table I (overleaf).

The cases of secondary glaucoma included nine of uveitis with increased intraocular pressure (Cases 5, 7, 8, 10, 12, 13, 16, 18, 19), of which three were also aphakic (Cases 12, 13, 18); one was secondary to an intumescent lens (Case 20), one was secondary to an intra-ocular foreign body with traumatic cataract (Case 11 ), and one followed perforating keratoplasty (Case 2).

The patients with congestive glaucoma included five cases of acute congestive glaucoma (Cases 3, 4, 9, 14, 15) and one of repeated subacute congestive episodes with peripheral anterior synechiae (Case 6).

In both patients with chronic simple glaucoma (Cases 1 and 17) operation was thought to be undesirable; Case 17 had had two previous drainage operations without adequate control, and Case 1 had already lost one eye through infection following a trephine operation.

In the earlier cases Diamox was only used if the patient had failed to respond to other means of therapy, but later, as the potentialities and indications became clearer, patients were treated with Diamox as the drug of choice, especially in secondary and congestive glaucoma.

* Based on a paper read to the Scottish Ophthalmic Club meeting in Edinburgh on March 12, 1955.

+ Received for publication April 12, 1955. 
TABLE I

\begin{tabular}{|c|c|c|c|c|c|}
\hline & & & & & \\
\hline $\begin{array}{l}\text { Case } \\
\text { No. }\end{array}$ & Age & Sex & Eye & Diagnosis & Previous History \\
\hline 1 & 75 & $\mathbf{M}$ & Bilateral & Chronic primary glaucoma & $\begin{array}{l}\text { Right trephine, 1954, followed by } \\
\text { panophthalmitis and encleation }\end{array}$ \\
\hline 2 & 65 & $\mathrm{~F}$ & Right & $\begin{array}{l}\text { Corneal degeneration; kerato- } \\
\text { plasty; secondary glaucoma }\end{array}$ & $\begin{array}{l}\text { Temporary reduction of tension with } \\
\text { eserine, pilocarpine, and cortisone }\end{array}$ \\
\hline 3 & 78 & $\mathbf{M}$ & Left & Acute congestive glaucoma & $\begin{array}{l}\text { Tension } 57-67 \mathrm{~mm} . \mathrm{Hg} \text {. Paracentesis } \\
\text { without relief }\end{array}$ \\
\hline 4 & 61 & $\mathbf{M}$ & Left & Acute congestive glaucoma & Bilateral exfoliation of capsules \\
\hline 5 & 39 & $\vec{M}$ & Left & $\begin{array}{l}\text { Disciform keratitis; secondary } \\
\text { glaucoma }\end{array}$ & Cortisone and homatropine \\
\hline 6 & 56 & $\mathbf{M}$ & Bilateral & $\begin{array}{l}\text { Subacute congestive attacks } \\
\text { of glaucoma }\end{array}$ & $\begin{array}{l}\text { Cupped discs, arcuate scotomata, } \\
\text { narrow angle with peripheral an- } \\
\text { terior synechiae. No response to } \\
\text { miotics }\end{array}$ \\
\hline 7 & 62 & $\mathbf{M}$ & Left & $\begin{array}{l}\text { Iridocyclitis; secondary } \\
\text { glaucoma }\end{array}$ & Iridocyclitis. Atropine given \\
\hline 8 & 55 & $\mathrm{~F}$ & Bilateral & Uveitis; secondary glaucoma & Delay of 2 months after diagnosis \\
\hline 9 & 43 & $F$ & Right & Acute congestive glaucoma & No response to miotics \\
\hline 10 & 64 & $\mathrm{~F}$ & Left & $\begin{array}{l}\text { Subacute uveitis; secondary } \\
\text { glaucoma }\end{array}$ & On atropine \\
\hline 11 & 41 & $\mathbf{M}$ & Left & $\begin{array}{l}\text { Traumatic cataract after intra- } \\
\text { ocular foreign body; } \\
\text { secondary glaucoma }\end{array}$ & No response to eserine and pilocarpine \\
\hline 12 & 57 & $\mathrm{~F}$ & Left & $\begin{array}{l}\text { Cyclitis after extracapsular } \\
\text { extraction; secondary } \\
\text { glaucoma }\end{array}$ & $\begin{array}{l}\text { First rise in tension controlled by } \\
\text { withdrawal of hyoscine }\end{array}$ \\
\hline 13 & 46 & $\mathbf{M}$ & Left & $\begin{array}{l}\text { Bilateral cyclitis with compli- } \\
\text { cating cataract extraction of } \\
\text { left lens; secondary glau- } \\
\text { coma }\end{array}$ & $\begin{array}{l}\text { Anterior synechiae and obliteration of } \\
\text { angle. Partial response to miotics }\end{array}$ \\
\hline \multirow[t]{2}{*}{14} & 54 & $\mathbf{M}$ & Bilateral & - & $\begin{array}{l}\text { Syphilis treated } 27 \text { years ago, recurrent } \\
\text { subacute glaucoma, cupped atrophic } \\
\text { discs, field changes; raised tension } \\
14.1 .55 \text { not controlled by eserine and } \\
\text { pilocarpine but controlled by D.F.P. }\end{array}$ \\
\hline & & & Left & Acute congestive glaucoma & Acute rise not reduced by miotics \\
\hline 15 & 83 & $\bar{F}$ & Bilateral & $\begin{array}{l}\text { Absolute glaucoma (right). } \\
\text { Acute congestive glaucoma } \\
\text { (left) }\end{array}$ & $\begin{array}{l}\text { Right eye blind for } 6 \text { years. Left, no } \\
\text { response to miotics }\end{array}$ \\
\hline 16 & 42 & $\mathbf{M}$ & Bilateral & $\begin{array}{l}\text { Iridocyclitis; secondary } \\
\text { glaucoma }\end{array}$ & $\begin{array}{l}\text { Right eye blind. Left no response to } \\
\text { atropine or iridectomy }\end{array}$ \\
\hline 17 & 67 & $\mathbf{M}$ & Bilateral & $\begin{array}{c}\text { Chronic glaucoma with re- } \\
\text { peated operations }\end{array}$ & $\begin{array}{l}\text { Bilateral trephine, right iridencleisis, } \\
\text { left cyclodialysis }\end{array}$ \\
\hline 18 & 72 & $\mathrm{~F}$ & Left & $\begin{array}{l}\text { Intracapsular extraction fol- } \\
\text { lowed by cyclitis; secondary } \\
\text { glaucoma }\end{array}$ & No response to miotics \\
\hline 19 & 70 & $\mathbf{M}$ & Right & $\begin{array}{l}\text { Bullous keratitis, uveitis; sec- } \\
\text { condary glaucoma }\end{array}$ & - \\
\hline 20 & 67 & $F$ & Right & $\begin{array}{l}\text { Intumescent lens; secondary } \\
\text { glaucoma }\end{array}$ & Mature cataract \\
\hline
\end{tabular}


PARTICULARS OF TWENTY CASES

\begin{tabular}{|c|c|c|c|c|c|c|}
\hline \multicolumn{2}{|c|}{$\begin{array}{c}\text { Ocular Tension } \\
\text { (mm. Hg) before } \\
\text { Diamox }\end{array}$} & \multirow[t]{2}{*}{$\begin{array}{l}\text { Date of } \\
\text { starting } \\
\text { Diamox }\end{array}$} & \multicolumn{2}{|c|}{$\begin{array}{c}\text { Ocular Tension } \\
\text { (mm. Hg) on } \\
\text { Diamox }\end{array}$} & \multirow[t]{2}{*}{$\begin{array}{l}\text { Duration of } \\
\text { Therapy } \\
\text { (weeks) }\end{array}$} & \multirow[t]{2}{*}{ Results } \\
\hline Right & Left & & Right & Left & & \\
\hline- & $31-36$ & 14.11 .54 & - & $17-20$ & 1 & $\begin{array}{l}\text { Only temporarily controlled. } \\
\text { Left trephine }\end{array}$ \\
\hline $\begin{array}{l}31-36 \\
31-36\end{array}$ & - & $\begin{array}{c}2.2 .55 \\
\text { and } \\
14.3 .55\end{array}$ & $\begin{array}{l}23 \\
17\end{array}$ & - & $\begin{array}{c}3 \\
\text { continuous }\end{array}$ & Controlled by Diamox \\
\hline- & 49 & 14.12 .54 & - & 26 & 4 days & $\begin{array}{l}\text { Only temporarily controlled. } \\
\text { Iridectomy }\end{array}$ \\
\hline- & 49 & 2.2 .55 & - & 25 & 10 days & $\begin{array}{l}\text { Control maintained with } \\
\text { pilocarpine }\end{array}$ \\
\hline- & $31-39$ & 29.1 .55 & - & $17-20$ & 10 & Controlled by Diamox \\
\hline 41 & 41 & 19.1 .55 & 26 & 23 & 11 & Controlled by Diamox \\
\hline- & 41 & 31.12 .54 & - & $17-20$ & 4 days & Controlled by Diamox \\
\hline 77 (P.L.) & $77(6 ; 18)$ & 13.12 .54 & 77 un & ed 77 & 6 hours & Not controlled. Iridectomies \\
\hline 90 & - & 16.11 .54 & 68 & - & 3 hours & Not controlled. Iridectomy \\
\hline- & 49 & 17.11 .54 & - & 26 & 16 & Controlled by Diamox \\
\hline- & 67 & 28.1 .55 & - & $23-26$ & 11 & Controlled by Diamox \\
\hline$\overline{-}$ & $\begin{array}{c}57 \\
31-36\end{array}$ & $\begin{array}{l}6.12 .54 \\
23.2 .55\end{array}$ & $\overline{-}$ & $\begin{array}{c}23-26 \\
26\end{array}$ & 16 & Controlled by Diamox \\
\hline- & $\begin{array}{l}31 \\
36\end{array}$ & $\begin{array}{l}22.11 .54 \\
\text { and } \\
26.1 .55\end{array}$ & - & $\begin{array}{l}17 \\
25\end{array}$ & $\begin{array}{r}2 \\
10\end{array}$ & Controlled by Diamox \\
\hline- & - & - & - & - & - & \\
\hline- & 67 & 25.1 .55 & - & 67 & 6 hours & Not controlled. Iridectomy \\
\hline $\begin{array}{c}67 \\
\text { (no P.L.) } \\
\end{array}$ & $\begin{array}{l}57-67 \\
(6 / 24) \\
\end{array}$ & $\begin{array}{c}- \\
11.2 .55 \\
\end{array}$ & - & - & $\begin{array}{r}- \\
1 \\
\end{array}$ & Controlled by Diamox \\
\hline - & 40 & 15.2 .55 & - & 19 & 8 & Controlled by Diamox \\
\hline 36 & - & 10.12 .54 & 23 & - & 8 & $\begin{array}{l}\text { Only temporarily controlled. } \\
\text { Right cyclodialysis }\end{array}$ \\
\hline- & $31-36$ & 21.2 .55 & - & 17 & 7 & Controlled by Diamox \\
\hline 49 & - & 7.3 .55 & 31 & - & 3 days & Not controlled. Paracentesis \\
\hline $49-57$ & - & 7.3 .55 & $15-17$ & - & 4 & Controlled by Diamox \\
\hline
\end{tabular}




\section{Results}

Cases were considered to be "controlled" where the ocular tension was lowered and remained at $26 \mathrm{~mm}$. $\mathrm{Hg}$ or below.

Diamox was considered to control a case if it reduced the tension by itself or if it was used in combination with other remedies which had failed to control the tension when used alone.

Cases were considered to be " not controlled" if the tension was lowered insufficiently and surgical intervention became necessary.

Secondary Glaucoma.-In this group of twelve cases, ten (Cases 2, 5, 7, 10, 11, $12,13,16,18,20)$ were considered controlled and two (Cases 8 and 19) not controlled.

In the two non-controlled cases the glaucoma was secondary to uveitis. One (Case 8) had been known to have bilateral secondary glaucoma 2 months before she came to the hospital and at that time the visual acuity in one eye was $6 / 24$, and the other eye was almost blind. The second patient (Case 19) was an old man aged 70 with bullous keratitis, uveitis, and secondary glaucoma; the ocular tension was lowered to $31-36 \mathrm{~mm}$. $\mathrm{Hg}$ and operative intervention was undertaken.

Congestive Glaucoma. - Of the six patients treated, three were considered controlled; one of these was controlled solely by Diamox (Case 4), whereas the other two (Cases 6 and 15) received Diamox and miotics but had not been controlled by the use of miotics alone. Two of the non-controlled cases showed so little improvement that operation was considered advisable (Cases 9 and 14); the sixth was only temporarily controlled (Case 3 ) and was subsequently operated upon.

Chronic Glaucoma.-Both patients treated with Diamox showed an adequate but only temporary reduction in pressure. In the first case (Case 1) the tension rose after 7 days of therapy and a trephine operation was carried out. The other case (Case 17) was controlled by Diamox for 8 weeks, but then the tension rose again and cyclodialysis was performed.

The detailed results are shown in Table I, and the cases are summarized in Table II.

TABLE II

SUMMARY OF RESULTS

\begin{tabular}{|c|c|c|c|c|c|}
\hline Type of Case & & $\begin{array}{l}\text { Number } \\
\text { Treated }\end{array}$ & $\begin{array}{l}\text { Number } \\
\text { Controlled }\end{array}$ & $\begin{array}{l}\text { Number not } \\
\text { Controlled }\end{array}$ & Remarks \\
\hline Secondary Glaucoma & $\cdots$ & 12 & 10 & 2 & - \\
\hline Congestive Glaucoma & $\ldots$ & 6 & 3 & 3 & - \\
\hline Chronic Glaucoma & $\ldots$ & 2 & $2^{*}$ & - & $\begin{array}{l}{ }^{*} \text { Control } \\
\text { only } \\
\text { temporary }\end{array}$ \\
\hline $\begin{array}{lll}\text { Total } & \ldots & \ldots\end{array}$ & $\ldots$ & 20 & $13\left(+2^{*}\right)$ & 5 & $\begin{array}{l}* \text { Control } \\
\text { only } \\
\text { temporary }\end{array}$ \\
\hline
\end{tabular}




\section{Dosage}

In congestive cases $500 \mathrm{mg}$. Diamox was given orally and repeated after 6 hours if necessary. As all our congestive cases happened to occur at the beginning of the series we have not used Diamox intravenously as recommended by American authors. The congestive cases controlled by Diamox have been taken off Diamox and are now controlled by miotics alone.

In all other cases $250 \mathrm{mg}$. Diamox was used orally every 6 hours with $30 \mathrm{gr}$. sodium bicarbonate. When the tension was controlled on this dosage, the dose of the drug was reduced to $250 \mathrm{mg}$. twice daily and later in the series to $125 \mathrm{mg}$. 6-hourly which was found to be more effective. After that the dosage may be further reduced to $125 \mathrm{mg}$. thrice or twice daily, and in some cases, especially of secondary glaucoma, the drug can be discontinued when the inflammatory process subsides.

The maintenance dose has to be worked out on a principle of trial and error. In one case $250 \mathrm{mg}$. 6-hourly was the only controlling dose; another required $250 \mathrm{mg}$. thrice daily, but most cases require less than that.

In the cases on a high maintenance dosage the serum potassium and sodium levels have remained within normal limits and the patients are well.

\section{Side-Effects}

All the patients complained of tingling in the fingers and toes even when on small doses of Diamox. Some experienced polyuria and thirst but were not apparently inconvenienced. Two complained of dyspepsia. One, who had had a peptic ulcer previously (Case 4), discontinued the drug and was very fortunately controlled on miotics after that; the other is taking the Diamox with a glass of milk (Case 13).

\section{Conclusions}

(1) Diamox can exert a powerful effect in lowering intra-ocular pressure.

(2) It reduces ocular tension in various forms of glaucoma, either alone or in conjunction with other drugs.

(3) Diamox seems to be particularly valuable as a method of therapy in cases of secondary and congestive glaucoma.

(4) In chronic simple glaucoma the tension is reduced by Diamox, but only temporarily; further studies in this form of glaucoma are desirable.

(5) Fairly heavy doses of Diamox can be given for long periods without troublesome side-effects.

\section{Summary}

Twenty cases of glaucoma treated with Diamox are reported. The results, dosage, and side-effects are discussed.

I wish to thank Dr. J. R. Paterson and Professor G. I. Scott for allowing me to treat cases under their care with Diamox. I also wish to express my gratitude to all members of the staff of the Eye Department, Royal Infirmary, Edinburgh, for their help and encouragement.

\section{REFERENCES}

BeCKer. B. (1954). Amer. J. Ophthal., 37, 13.

Grant, W. M., and Trotter, R. R. (1954). Arch. Ophthal. (Chicago), 51, 735. 